\title{
ASSESSMENT OF STRUCTURAL EFFICIENCY OF AN EXISTING BUILDING STRUCTURE BY PERFORMING NON-DESTRUCTIVE TESTS: A CASE STUDY
}

\author{
Rushabh Karnavat ${ }^{1}$, Vivek Singh ${ }^{2}$ \\ ${ }^{1}$ General Manager, Creative Consultants, Mumbai \\ ${ }^{2}$ C.E.O, Creative Consultants, Mumbai
}

\begin{abstract}
Spalling of concrete and corrosion of steel, Exposure of steel reinforcement, leakage due to improper drainage are affected by the structure or layout change in original design which may increase the dead load on the structure and reduced strength of structures. It may lead to structural deficiency and hence there is a need to identify the livability of the existing structures. With the help of structural audit it is possible to prevent any unexpected failures of any part or as a whole of structure and will give an assurance and economical solution for the residents. It is the need of the hour to raise exigent demand for raising the awareness and standardizing such procedures. The complete performance of a building needs to be examined its service life as well as to know the real status of building. Multiple Cracks of plaster, spalling of concrete and corrosion of reinforcement, Exposure of steel reinforcement, Major Cracks, leakage due to improper drainage etc. etc. this are common problems causes the building damaged. These localized distresses will get accelerated, if not taken care of at the right time, which may lead to damage of structure resulting in even loss of life.
\end{abstract}

\section{INTRODUCTION}

Shreeji Apartment C.H.S. Ltd. is located at Dahanu, Maharashtra. The building is a R.C.C. frame structure having Ground +4 storeys. Shops are located at ground floor of the building. Fieldwork started from 6th February, 2017 and the entire work was completed by 9th February, 2017. Preliminary drawing preparation, Visual inspection and tapping was carried out simultaneously; results of the same are presented in this document. Non Destructive Tests such as Ultrasonic-pulse velocity test, Carbonation depth measurement, Rebound hammer test, Chemical Test, Core Cutting Test, Half-cell potentiometer test, Cover meter test etc. were carried out.

\section{PRINCIPLES}

The building was investigated in detail for inspection from inside and outside thoroughly. Various structural load bearing R.C.C. members such as columns, beams \& slabs within the structure were observed for a range of defects such as cracks, spalls, crazing, seepage etc. All these defects are marked on the observation sheets with approximate repair area which helped in compiling the total data of the structure. Various symbols used in floor plan are as per attached legend sheet. Maximum number of columns $\&$ beams inside the flat were subjected to tapping by 3 different types of hammers. For residential building structure, medium hammer will be the most effective which gives delams from $10 \mathrm{~mm}$ to $25 \mathrm{~mm}$ depth. The hollow sound was recorded in the observation sheets as hollow, which was evaluated for Remedial measures. Rusting of Iron and steel is the most commonly known process of Corrosion. The following equation describes the formation process of rust:

$$
\begin{array}{cc}
2 \mathrm{Fe}+\mathrm{H} 2 \mathrm{O}+11 / 2 \mathrm{O}_{2} & ---\quad 2 \mathrm{FeO}(\mathrm{OH}) \\
\text { Iron + Water + Oxygen } & \text { Hydrated Iron Oxide }
\end{array}
$$

Concrete is permeable to water and solution of Chloride \& Sulphate. Penetration of the solution of these chemicals can produce a gradual change in the condition within the concrete ultimately leading to Corrosion of steel and deterioration of concrete. Because of the chemical attack the concrete carbonation starts and the concrete loses its alkalinity. Major constituents like Carbon dioxide, Sulphates, Sulphor dioxide etc. cause the loss of alkalinity in concrete. Any corrosion of reinforcement results in the formation of rust, which occupies a volume of about 2.2 times that of iron from which it is formed. This corrosion product has literally no place to go so that it produces large internal pressure as high as 1 ton/inch ${ }^{2}$ around the concrete resulting in longitudinal cracks parallel to reinforcement and cracks the concrete.

\section{OBSERVATIONS}

\section{External}

The exterior face of the building shows cracks in external plaster at many locations, heavy vegetation growth observed at external face as well as plumbing joints. Major structural cracks and exposure of reinforced steel was found at various locations during the survey. Plumbing and sanitation lines at external walls of the building are in a poor condition. Leakage marks are found at the pipe joints of the plumbing lines at many places externally. 


\section{Internal}

Many layout changes in the flats have been done by tenants of the building. However, these layout changes may affect the building structure in the long run. Hence, there should not be any further layout/structural changes inside the flat for the better health of the building structure. Leakage \& seepage marks are observed inside the flats due to internal wall to wall leakages with damaged external plaster \& formed cracks. Major structural cracks and exposure of steel is observed in R.C.C. load bearing members. Corrosion of steel and spalling of concrete is observed in R.C.C. members at many locations.

\section{RCC Frame}

The observations are based on visual survey and Non Destructive Tests conducted by our team of Engineers. An extensive investigation to collect full details and scope of repairs has been carried out. Observations are prepared in this effect, and the same are attached with this report. The R.C.C. members are in a highly distressed condition.

\section{Water-Proofing}

We observed I.P.S finish on the terrace floor. Leakage from the terrace floor has been observed in the flats due to the damaged condition of the terrace waterproofing. Vegetation growth is observed near pipe joints. Refer exhibits for more details. The headroom was observed to be in distressed condition. Due to the spalling of concrete in the headroom area, the concrete reinforcement was found to be exposed. Leakage and dampness observed in headroom ceiling. Cracks in parapet wall observed at few location. Absence of chajja was observed in the entire building during the survey. Refer exhibits for more details.

\section{Staircase and Passage}

Staircase \& passage areas were observed in highly distressed condition. Major structural cracks have developed in members at many locations. All the R.C.C. Jali in the staircase and passage area was found to be in dilapidated condition. Dampness was observed in the staircase $\&$ passage walls due to leakage from duct area.

\section{Pavement}

The building pavement was observed to be in distressed condition and requires major repair work at the earliest.

\section{Compound Wall}

Compound wall is in poor condition and require repair work at the earliest. Painting can be done on compound wall as well as on grills as a beautification \& durability point of view.

\section{INSTRUMENTATION}

Following tests were carried out (Non-Destructive Test):

1. Ultrasonic Pulse Velocity Test: To assess the homogeneity of concrete and find the cracks presence in concrete.

2. Rebound Hammer: To find out the compressive strength of concrete, to know the hardness of concrete

3. Half-Cell Potentiometer Test: To determine the Probability of corrosion in the embedded steel

4. Carbonation Test: - To assess depth of carbonation

5. Core Cutting Test: To calculate compressive strength, density of concrete.

6. Cover Meter Test: - To measure cover of reinforcement, diameter of reinforcement and spacing of reinforcement

\section{RESULTS \& DISCUSSIONS}

1. Ultrasonic Pulse Velocity Test

The readings in this case are in range of $2.21 \mathrm{Km} / \mathrm{sec}$ to $3.15 \mathrm{Km} / \mathrm{sec}$ and the average reading is $2.67 \mathrm{Km} / \mathrm{sec}$, which indicates concrete quality to be doubtful.

\section{Rebound Hammer Test}

The readings in this case are in range of 24.4 to 33.6, average reading is 28.3 \& average Equiv. Cube strength is $19.34 \mathrm{~N} / \mathrm{mm} 2$, which indicates satisfactory concrete strength.

\section{Half-Cell Potential Test}

The readings lie between $-367 \mathrm{mV}$ to $-400 \mathrm{mV}$ which indicates that the approximately $90 \%$ probability of corrosion of reinforcement.

\section{Carbonation Depth Measurement Test}

Depth of carbonation in R.C.C. members are in range of $50 \mathrm{~mm}$ to $82 \mathrm{~mm}$ and average depth of carbonation is $63.8 \mathrm{~mm}$, which indicates $76 \%$ carbonation of concrete.

\section{Core Test}

The equivalent cube strength of concrete is $20.4 \mathrm{~N} / \mathrm{mm} 2$ which is satisfactory strength of concrete.

\section{Chemical Test}

The average chloride content and sulphate content of concrete was found to be $115 \mathrm{mg} / \mathrm{l}$ and $100 \mathrm{mg} / \mathrm{l}$ respectively, which is within the permissible limits. The average $\mathrm{pH}$ Value was found to be 9.75 which is within the permissible limits.

\section{Cover Meter Test}

The average concrete cover in columns was found to be $62 \mathrm{~mm}$.

\section{CONCLUSION}

1. As observed, there are many types of distress noted mainly related to serviceability issues like leakage through existing damaged external plaster, major structural cracks in R.C.C. members like columns, beams and slabs, cracks in masonry walls. However the 
defects and damages need to be repaired at the earliest for stability of building.

2. As per Non Destructive Test (N.D.T.) results the R.C.C. members are in a highly distressed condition. It needs major structural repair immediately for the stability and Durability of the building.

3. Various cracks like shear cracks, separation cracks, thermal expansion cracks, and structural cracks are major defects in plaster that are causing leakage problems in the building.

4. As per the observation and detail survey, the defect in the R.C.C. members are due to the effect of corrosion, continues drying \& wetting process in the vicinity of R.C.C. section. The propagation of defects will proceed faster once the entire concrete cover has deteriorated.

5. Various alterations \& modifications have been made in the layout of the building structure by the tenants in the past which has adversely affected the structure over the period of time.

6. The building is having usual ageing problem and need repair work immediately. The building is in repairable condition and by undergoing major structural / civil repairing work, it can be brought to stable condition. The repairs mentioned in this report should be carried out at the earliest under technical and professional supervision.

\section{RECOMMENDATIONS}

As per the actual observations after detailed survey, following measures are recommended as the best remedial measures to meet safety standards considering the type of defects:

1. Looking into all aspects of the building maintenance and as per detailed survey, the building needs major structural \& civil repair in a proper planned manner immediately.

2. It is desirable to strengthen the R.C.C. members internally and also externally wherever necessary. The internal and external R.C.C. members need to be repaired by Polymer Modified Mortar (P.M.M.) \& Micro Concrete (M.C.) technique. The above technique should be also applied for slabs where delamination is observed.

3. Strengthening of the R.C.C. members i.e. slab, beam, column, etc. can be done with various repair \& retrofitting techniques like fiber wrapping, jacketing method, injection grouting or any other suitable method. Use of structural steel channel members for additional strength \& better distribution of dead \& live load can be made.

4. Fibre Reinforced Concrete (F.R.C.) can be used to enhance the properties of concrete. In F.R.C. a number of small fibres are dispersed and distributed randomly in the concrete at the time of mixing, and thus improve the concrete properties in all directions.

5. These fibres help to transfer the load to internal micro cracks and have excellent flexural-tensile strength, resistance to spitting, impact resistance, excellent permeability and frost resistance.
6. These fibres have many benefits, steel fibres improve the structural strength and reduce the heavy steel reinforcement. Polypropylene and Nylon fibres are used to improve the impact resistance.

7. As the existing plaster is in damaged condition at many locations, cracks and heavy vegetation growth was observed at many of places, hence full plaster work is recommended to the external facade of the building.

8. Staircase, headroom also needs to be treated from internally and externally through major structural, civil repair work on urgent basis.

9. Leakages are observed in plumbing lines, hence there is a need to change the plumbing lines with proper G.I. Clamping and maintaining suitable distance from the walls.

10. Waterproofing over terrace was observed in damaged condition. However based on actual observation from inside the flat, dampness is observed due to leakage from terrace, it is a need of hour to retrofit the terrace floor with injection grouting / brickbat coba method/ chemical or crystalline waterproofing etc. or any other suitable method.

11. Absence of chajja was observed above the windows/openings in the entire building. The peripheral chajja below the terrace was observed in dilapidated condition hence it is recommended to construct ferro-cement chajja.

12. Passage and Staircase common area is in a highly distressed condition. However, major structural crack and exposed steel reinforcement is to be repaired by Polymer Modified Mortar (PMM) \& Micro Concrete technique followed by internal plaster which will provide a good finish to the surface. Replacement of the reinforcement is suggested, wherever required.

13. The existing painting was found in poor condition we recommend full synthetic texture to the external facade along with acrylic or elastomeric painting as a beautification \& durability point of view.

14. P.C.C. Pavement area is in distressed condition and we recommended to go major repair work for pavement also.

15. Compound wall is in poor condition and requires repair work. However painting can be done on compound wall as well as on grills as a beautification $\&$ durability point of view.

As per adverse weather effects we advise, the building should be renovated after every $9-11$ years, for the safety of the building and Durability point of view. The Building is in highly distressed condition \& needs immediate structural/civil repair work of R.C.C. members \& other damaged areas of the building externally and internally wherever required in the flats. Delay in planning in retrofitting program, not only increases the distress level but also increases the danger to human life. 


\section{REFERENCES}

[1] J. J. Shah (2008), Article in The Indian Concrete Journal, pp. $17 \square 26$.

[2] Indian Standard: 13311:1992 (Part 1) NDT methods of Test- Ultrasonic Pulse

[3] Velocity.

[4] Indian Standard: 13311:1992 (Part 2) NDT methods of Test- Rebound Hammer.

[5] ACI 546R-04 - Concrete repair guide.

[6] ACI 562-12 - Code Requirements for Evaluation, Repair, and Rehabilitation of

[7] Concrete Buildings.

[8] Indian Standard: 456: 2000- Plain and Reinforced Concrete - Code of Practice (Fourth Revision).

[9] Indian Standard: 516: 1959- Method of test for strength of concrete.

[10] Building and Construction Authority, "Periodic Structural Inspection of Existing Buildings", January 2012 Central PWD, "Handbook on repair and rehabilitation of RCC Buildings", July 2010 